ОСОБЛИВОСТІ СТАНОВЛЕННЯ ПРОФЕСІЙНОЇ Я-КОНЦЕПЦІЇ В ОНТОГЕНЕЗІ

\title{
KEY ELEMENTS OF PROFESSIONAL SELF-CONCEPT DEVELOPMENT IN ONTOGENY
}

У статmі розелянуті особливості становлення профресійної «Я-концепції» в онтогенезі. Розкриваються теоретичні передумови дослідження та їі формування на різних етапах розвитку особистості. Особливу увагу приділено роботам вітчизняних психологів у иій галузі. Показано вплив соціуму й навколишнього середовища на фрормування особистісних цінностей. Розкриті особливості впливу пріоритетів і цінностей на спрямованість у професійному самовизначенні. Вивчені особливості фоомування «Я-концепції» та визначення життєвого шляху в старших школярів. На підставі методики ціннісних орієнтацій Шейна виділені компоненти, які впливають на професійну «Я-концепцію». На основі виділених компонентів розкриті особливості онтогенезу розвитку професійної «Я-концепції» від школяра до випускників вищих навчальних закладів. Розглянуто питання гендерних відмінностей під час формування професійної «Я-концепціі»». Емпірично обгрунтовано, що для чоловіків професійна самореалізація має більшу значимість, ніж для жінок. Розглянута динаміка змін ціннісних пріоритетів в онтогенезі від школяра старших класів до випускника вишу. Показані відмінності в ціннісних пріоритетах у студентів молодших і старших курсів. На підставі цього розкрито прочес трансформації професійної «Я-концепції» від особистісних потреб самореалізації через профресійну діяльність до ціннісних орієнтацій використовувати профессію як можливість удосконалити світ і зробити його кращим. Емпіричним шляхом показана важливість інтеграції різних сфрер життя в професійному самовизначенні, а також соціальна важливість профресії. Показано взаємозв'язок між розкриттям професійного потенціалу та реалізацією особистості в інших ссрерах (сімейній, культурній тощо). У зв'язку з динамічними змінами навколишнього середовища, швидким розвитком технологій і появою нових видів діяльності показано ставлення сучасної молоді до профресійної експертності.

Ключові слова: особистість, потенціал, особистісно-профресійний потенціал, Я-кончепція, онтогенез.
The article examines key elements of professional self-concept development in ontogeny. The theoretical prerequisites of research and its formation at various stages of personality development are revealed. Particular attention is paid to the work of Ukrainian psychologists in this area. The influence of society and the environment on the formation of personal values is shown. The features of the influence of personal priorities and values on the orientation in professional self-determination are revealed. The features of the formation of the "self-concept" and the definition of the way of life in the high school students are revealed. On the basis of Shane's methodology of value orientations, the components influencing the professional "self-concept" were identified. On the basis of the identified components, the features of the ontogenesis of the development of the professional "self-concept" from high school students to college graduates are revealed. The issue of gender differences in the formation of a professional "self-concept" is revealed. It is empirically substantiated that for men professional self-realization is of greater importance than for women. The dynamics of changes in value priorities in ontogenesis from a high school student to a university graduate is considered. The differences in value priorities among junior and senior college students are shown. On the basis of this, the process of transformation of the professional "self-concept" from personal needs of self-realization through professional activity to value orientations to use the profession as an opportunity to improve the world and make it better is revealed. Empirically, the importance of integrating various areas of life in professional self-determination is shown, as well as the social importance of the profession. The relationship between the disclosure of professional potential and the realization of the individual in other life's areas (family, cultural, etc.) is shown. In connection with the dynamic changes in the environment, the rapid development of technologies and the emergence of new types of activity, the attitude of modern youth to professional expertise is shown.

Key words: personality, personal and professional potential, resources, environment, and professional activity.
Постановка проблеми. Важливими умовами повноцінного розвитку особистості $€$ її усвідомлене прагнення до максимально повного розкриття й реалізації власних потенційних можливостей, здатність самостійно визначати свій життєвий шлях і досягати поставлених цілей. Процес особистісного і професійного самовизначення $є$ непростим, оскільки, з одного боку, існування в соціаль- ному середовищі висуває вимоги до адаптації особистості в суспільстві, а з іншого самореалізація тісно пов'язана з унікальністю й неповторністю людини.

Аналіз останніх досліджень і публікацій. Під час аналізу вищої освіти ми відзначили різноманіття методичних і методологічних підходів до питання особистісно-професійного потенціалу. Передусім варто відзначити інди- 
відуально-орієнтовану парадигму: А. Маслоу, К. Роджерс, Л.С. Виготський, Б.С. Братусь, А.Г. Асмолов, Л.А. Петровська, І.Н. Семенов, В.П. Зінченко. Величезний вплив на розвиток гуманістичної парадигми особистісно-орієнтованої освіти мали Е.Ю. Пряжникова, Н.С. Пряжников, А.П. Валицька, К. Ясперс, І.С. Якиманська, В.Н. Фурс, Г.М. Бреслав, Н.М. Швальова, Ю.В. Варданян, Г.М. Борліков, Н.С. Макоєва, Д.В. Тирсиков та інші. Соціально-орієнтуюча й професійно-розвивальна парадигма навчання представлена в роботах Е.А. Яблокова та Н.В. Боровикова. Компетентнісний підхід представлений у працях А.Г. Бермус, І.А. Зимова, А.В. Хуторської.

Серед вітчизняних психологів особливо цінні роботи В.Н. Подшівалкіної про соціальні умови й тенденції використання потенціалу особистості; Ж.П. Вірни про особливі ресурси професійної адаптації; С.В. Ситнік, який розглядає особливий потенціал як умову професійної взаємодії; О.Є. Фурман вивчає Я-концепцію; А.М. Большакова розкриває особливу реальність людини в онтогенезі; М.А. Садова досліджує психологічні складники потенціалу самореалізації особистості; Г.В. Дерябіна розглядає особливості управлінського потенціалу особистості; інших.

Суперечки, що зростають, у психологічному середовищі, що ж зумовлює процес розвитку - навколишне середовище або генетична обдарованість, передані у спадок, привели В. Штерна до створення теорії конвергенції. Він уважав, що психічний розвиток $€$ результатом конвергенції внутрішніх задатків особистості із зовнішніми умовами навколишнього середовища. Теорія конвергенції робить акцент на тому, що розглядає процес психічного розвитку як сукупність факторів: Х-елементи спадковості та Ү-елементи середовища. Теорія конвергенції - найпоширеніша концепція в сучасній зарубіжній психології. До сих пір психологи продовжують зважувати ці два фактори [1].

Постановка завдання. Говорячи про потенціал особистості, ми повинні розуміти, що сам по собі він $є$ нейтральним ресурсом, який може розкритися або залишитися незадіяним залежно від розвитку життєвого сценарію особистості. Отже, ми можемо говорити про те, що реалізація особистісного потенціалу визначає життєву спрямованість індивідуума. Вона дає можливість особистості використовувати свої ресурси, перетворюючи ї у можливості. Існує інтегральний взаємозв'язок особистісного потенціалу з професійним потенціалом, що дає нам можливість виділити категорію особистісно-професійного потенціалу [2].

Ми виходимо з того, що формування особистісно-професійного потенціалу почина- ється 3 підліткового віку й відображається в процесі навчання. Професійне самовизначення - це процес і компонент професійної самосвідомості, який впливає на самостійність професійного вибору суб'єкта, на формування внутрішніх структур особистості та їх оптимальне використання в діяльності, вироблення внутрішніх критеріїв оцінювання себе як професіонала, знаходження особистісних смислів у трудовій діяльності, є початковим етапом формування особистісно-професійного потенціалу.

Тому для дослідження ми взяли школярів, які перебувають на етапі закінчення школи (11 класу) і планують вступати до вищого навчального закладу.

Однак хочеться відзначити, що проблема професійного самовизначення, а отже, і розвитку та становлення особистісно-професійного потенціалу залишається актуальною для людини протягом усієї професійної кар'єри. I дуже часто, люди закінчивши виш, або ідуть працювати не за фахом, або опановують другу освіту. Саме у зв'язку з цим для дослідження ми запросили також випробовуваних, які закінчили виш більше ніж 5 років тому.

Особистісно-професійний потенціал є важливим психологічним поняттям, що визначає одні 3 найголовніших особливостей самореалізації людини, становлення її життєвого шляху, формування життєвих стратегій. Вивчення особистісно-професійного потенціалу є досить складним завданням, оскільки це поняття ще досить нове в сучасній психологічній науці й має неоднакове визначення в рамках наявних психологічних теорій і шкіл, тому будь-яка спроба емпіричної операціоналізації цього поняття є досить важким завданням. Але це дає нам змогу використовувати різні психологічні методики, які в тому чи іншому аспекті фіксують окремі прояви особистісно-професійного потенціалу.

Виклад основного матеріалу дослідження. У дослідженні взяли участь 150 випробовуваних. У головній групі випробовуваних студентах, узяло участь 90 осіб, 45 із них - це студенти 1-3 курсів, 45 респондентів - це студенти 4-5 курсів. У групі школярів і випускників вишів узяло участь по 30 осіб у кожній групі. Усього в дослідженні взяли участь 89 жінок і 61 чоловік.

Планування кар'єри та її самореалізація $€$ одним із найважливіших факторів розвитку особистісно-професійного потенціалу. Професійна «Я-концепція» базується на уявленні людини про свою особистість, розумінні своїх здібностей і втіленні їх у професійному шляху. Під час вибору кар'єри для особистості відіграють ключову роль не тільки їі здібності й таланти, а і особисті мотиви й ціннісні орієнтації, що базуються на підставі ії життєвого 
досвіду. Життєвий досвід особистості формує соціальні установки щодо кар'єри та професійного розвитку. Тому, говорячи про формування професійної Я-концепції, ми зобов'язані розглядати ії через призму соціальних установок, ціннісних орієнтацій, інтересів і соціально обумовлених факторів діяльності [3].

Узявши за основу методику Е. Шейна «Якорі кар'єри» і його розуміння професійної Я-концепції, ми виділили складові компоненти професійної картини світу й знайшли відповідні їм шкали із цієї методики. Ми виділили такі компоненти: професійна праксеологічність (шкала «менеджмент» за Шейном); профорганізаційна стабільність (шкала «стабільність» за Шейном); професійна експертність (шкала «професійна компетентність» за Шейном); професійний менеджмент (шкала «підприємництво» за Шейном); професія як частка життя (шкала «інтеграція стилів життя» за Шейном); соціальна значимість професії (шкала «служіння» за Шейном); професія як поле самореалізації (шкала «виклик» за Шейном); професійна самодостатність (шкала «автономія» за Шейном).

Оцінюючи результати, отримані нами в досліджуваній вибірці, ми можемо помітити, що найбільш виражені такі компоненти з пропонованої нами моделі: професія як частина життя $(7,68$ балів із 10$)$ і соціальна значимість професії (7,54 бала з 10$)$.

Це свідчить про те, що нинішне покоління, розвиваючи себе в контексті професіонала, не готове ґрунтуватися лише на професійній діяльності, для нього важливі й інші сторони життя. Кар'єра сучасного випускника все більше пов'язує успішність діяльності із цілісністю людського потенціалу, при цьому професійний потенціал пов'язаний із реалізацією людини в різних сферах, не тільки в професійній діяльності, а й у дозвіллі, сімейній, культурній тощо. Такі люди більше цінують своє життя загалом, ніж конкретну роботу, кар'єру або організацію, що відображено в досить високих показниках за критерієм «професія як частина життя» в усіх групах опитаних.

Наступний високий показник, який ми отримали, - це показник за критерієм «соціальна значимість професії» $(7,54)$. Як описує Шейн, основними цінностями за цієї орієнтації $€$ такі соціальні спрямованості, як «служіння людству», «бажання зробити світ кращим», «допомога людям» і «робота з людьми» [4]. Це наводить нас на думку, що професіоналізм розуміється школярами, студентами й випускниками не тільки як джерело фінансової незалежності, а і як якесь професійне служіння суспільству та клієнтам. Як зазначає Е. Шейн, люди з подібною спрямованістю в кар'єрній орієнтації відмовляться працювати в установах, які вороже налаштовані до їхніх життєвих цінностей і цілей. Вони швидше будуть готові відмовитися від кар'єрного зростання або переходу на іншу більш оплачувану роботу, якщо нова посада або робота не дадуть можливості реалізувати їхні життєві цінності й переконання. Так, наприклад, зараз ми можемо спостерігати високу тенденцію залученості сучасної молоді до питань кліматичних і політичних змін світу.

Особливий інтерес, на наш погляд, викликав той факт, що орієнтація на професійну експертність $(5,53)$ має найнижчі показники й посіла 8 місце серед нашої вибірки, тобто на останнє. Чи є це ознакою того, що сучасна молодь не прагне стати професіоналом своєї справи? Цей був би занадто поверховий погляд. Ми бачимо в цьому критерії тенденцію до того, що завдяки швидкому розвитку технологій і постійно мінливим реаліям і вимогам життя сучасна молодь більше не ставить професійну експертність на перше місце, люди готові змінювати професії, пробувати себе в нових галузях, накопичувати абсолютно нові знання й навички. Більш того, за останні 20 років ми спостерігаємо величезний стрибок щорічно нових професій, а відповідно, і навичок, якими повинні володіти фахівці. I це повністю підтверджує думку Елвіна Тоффлера, одного з авторів концепції постіндустріального суспільства, який сказав таке: «У XXI столітті вважається безграмотним уже не той, хто не вміє читати й писати, а той, хто не вміє вчитися, доучуватися й переучуватися» [5].

Порівнюючи гендерні групи, особливих відмінностей ми не виявили. Як для чоловіків, так і для жінок на першому місці є «професія як частина життя» (чоловіки - 7,41; жінки - 7,82), а на другому - «соціальна значимість професії» (чоловіки - 7,22; жінки - 7,72), що повністю збігається з тенденцією в загальній вибірці випробовуваних, однак у жінок показники по 5 шкалах вищі, ніж у чоловіків.

Ми можемо виділити 3 шкали, у яких показники в жінок нижчі: «професійна компетентність», «професія як поле самореалізації» і «професійний менеджмент». Отже, ми доходимо висновку, що для жінок професійна самореалізація має меншу значимість порівняно з чоловіками, а також потреба займати керівну посаду. Це зовсім не заперечує той факт, що жінки мають спрямованість у цьому, але порівняно з чоловіками для них це менш важливо.

Тепер зробимо порівняльний аналіз усіх чотирьохгруп випробовуваних і розглянемо, як по-різному розподілилися пріоритети в кожній віковій групі. Дуже важливим, на наш погляд, $€$ той факт, що, згідно з методикою Е. Шейна, випробовувані відповідали на питання й самі оцінювали за шкалою від 1 до 10 важливість того чи іншого «якоря кар'єри». 


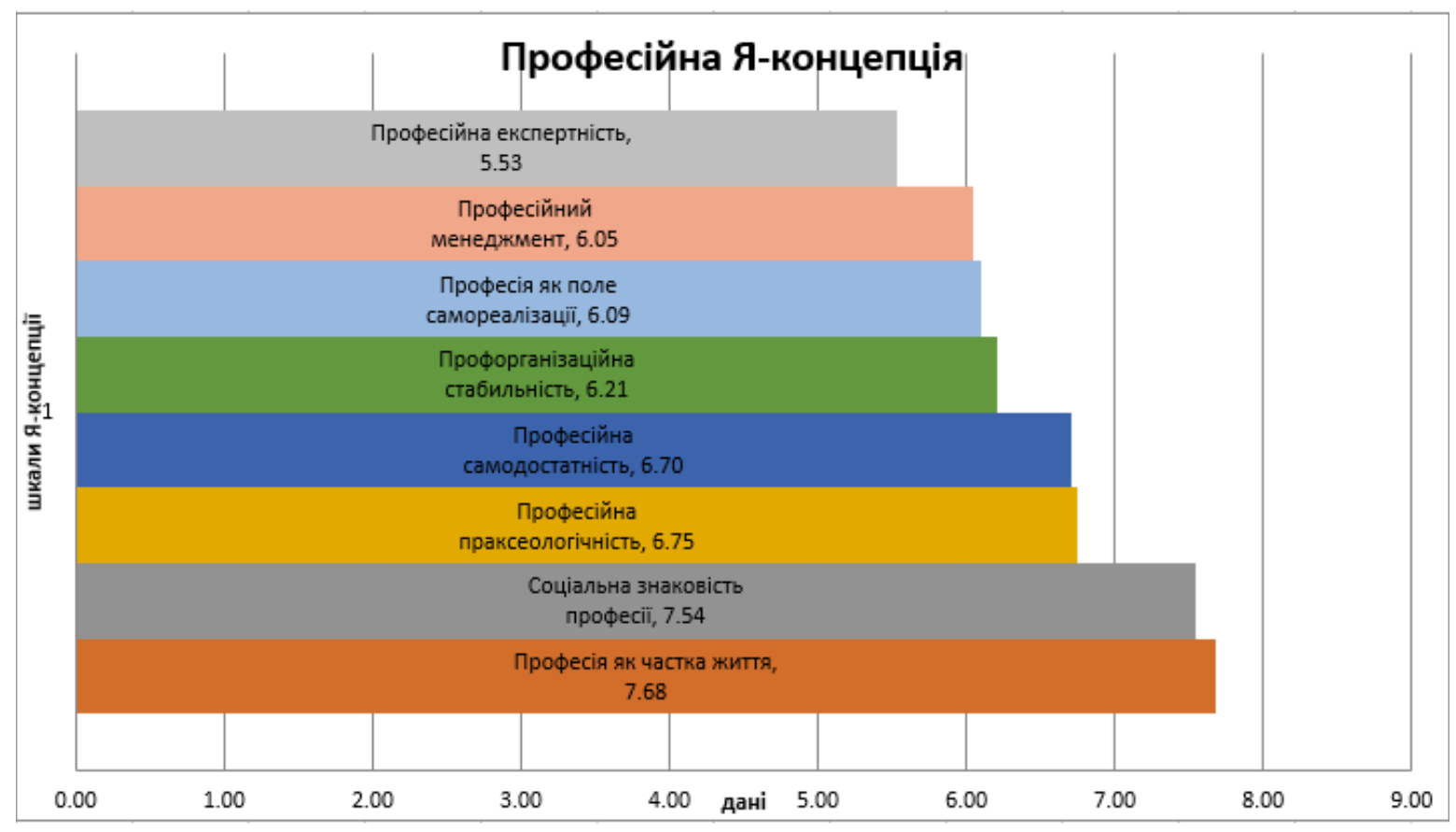

Рис. 1. Професійна Я-концепція

Отже, усі відповіді базувалися на основі їх суб'єктивного аналізу, тому для нас найбільш цікавим для інтерпретації результатів $€$ не самі по собі показники компонентів, а саме динаміка між групами випробовуваних і їх взаємозв'язок. Так, наприклад, показники школярів практично за всіма компонентами вищі, ніж показники випускників. Це пояснюється тим, що професійні плани старшокласників часто недостатньо конкретні. Для ранньої юності характерна надмірна оптимістичність у визначенні можливих термінів досягнення успіху й життєвих цілей. Так як саме в цьому віці характерно формування життєвих планів, цілей і мрій про майбутнє, цей період ми можемо однозначно охарактеризувати як період, у якому починає формуватися професійна Я-концепція, формування життєвого плану відбувається в результаті конкретизації цілей, мотивів і розуміння прийнятних для особистості способів досягнення поставлених цілей. Головна відмінність життєвого плану від мрії полягає в тому, що мрія абстрактна, а життєвий план - це конкретні розроблені кроки діяльності [6].

Однак для цього віку також характерний максималізм у судженнях і висновках. Саме цим, на наш погляд, зумовлені більш високі показники практично за всіма компонентами в школярів, ніж в інших групах випробовуваних.

Під час порівняння груп ми спостерігаємо таку картину: для школярів і студентів 4-5 курсів на першому місці в становленні професійної Я-концепції є орієнтація на інтеграцію різних сторін способу життя (шкала «професія як частина життя»: школярі - 7,9; студенти
4-5 курсів - 7,79). Вони нехочуть, щоб у їхьому житті домінувала тільки кар'єра, або тільки сім'я, або тільки саморозвиток, а прагнуть до того, щоб усе це було збалансовано.

Для випускників же і студентів 1-3 курсів на першому місці виявляється "соціальна значимість професії» (випускники - 7,97, студенти 1-3 курсу - 7,68). Для них набагато важливіше, щоб та діяльність, якою вони займаються, приносила користь суспільству.

Розглядаючи кожну вікову групу окремо, ми можемо відзначити такі особливості. Показники школярів за 6 компонентами вищі, ніж в інших груп випробовуваних. Як ми згадували вище, це пов'язано саме з юнацьким максималізмом і бажанням оцінювати результати за шкалою від 1 до 10 в максимально високих або низьких показниках. Однак цікавий той факт, що за двома параметрами група школярів знаходиться не на першому місці: «профорганізаційна стабільність» і «соціальна значимість професії». На наш погляд, це дуже цікавий показник і він свідчить про те, що школярі перебувають у процесі формування професійної Я-концепції, для них стабільність місця роботи ще не $є$ настільки важливою, як для інших, більш старших груп випробовуваних. Також соціальна значимість професії, посідаючи друге місце за важливістю серед школярів, при цьому має результати нижчі, ніж в інших групах випробовуваних. Професійна компетентність, як і в загальної вибірки, знаходиться на останньому місці. На наш погляд, це також пов'язано з початковим етапом формування професійної Я-концепції й дуже загальними уявленнями про майбутню професію та свої здібності. 


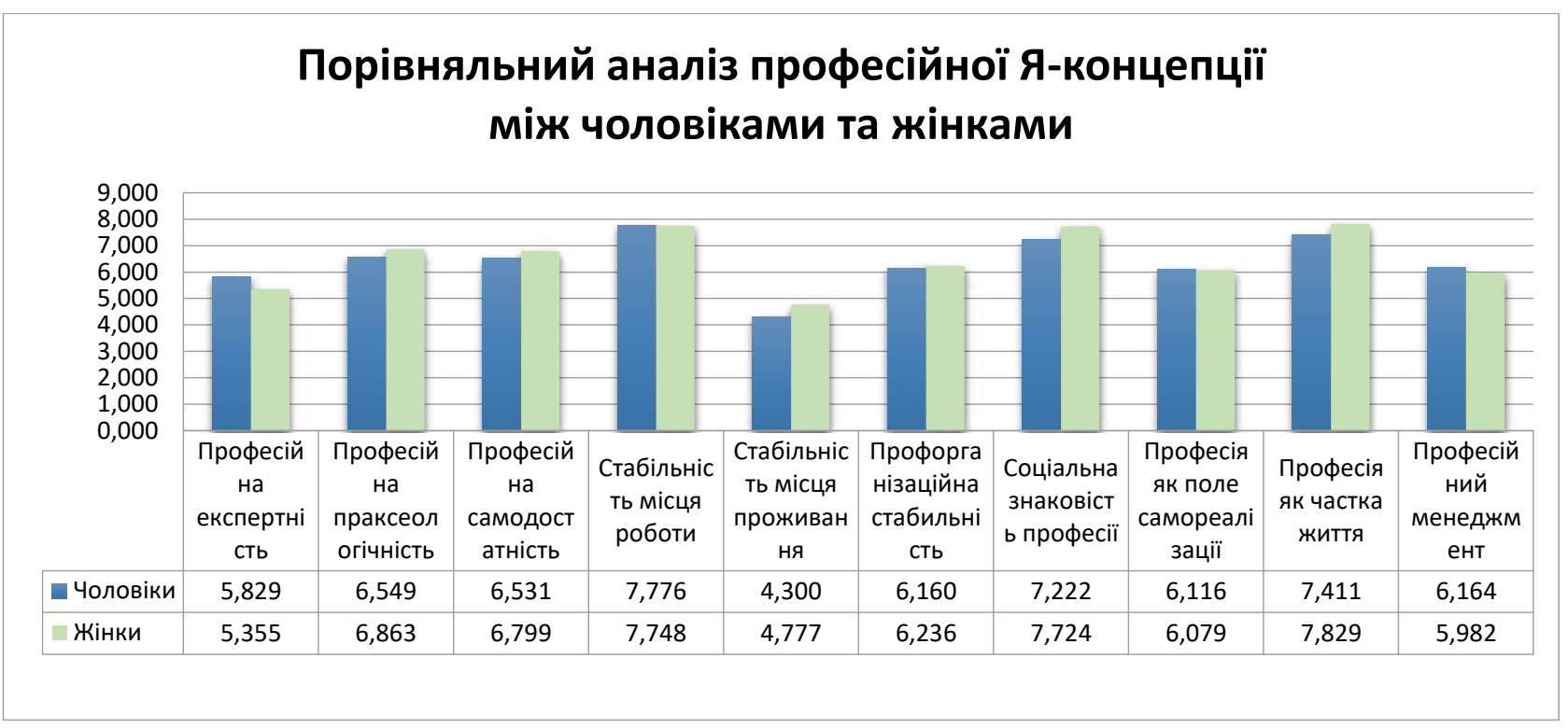

Рис. 2. Порівняльний аналіз професійної Я-концепції між чоловіками та жінками

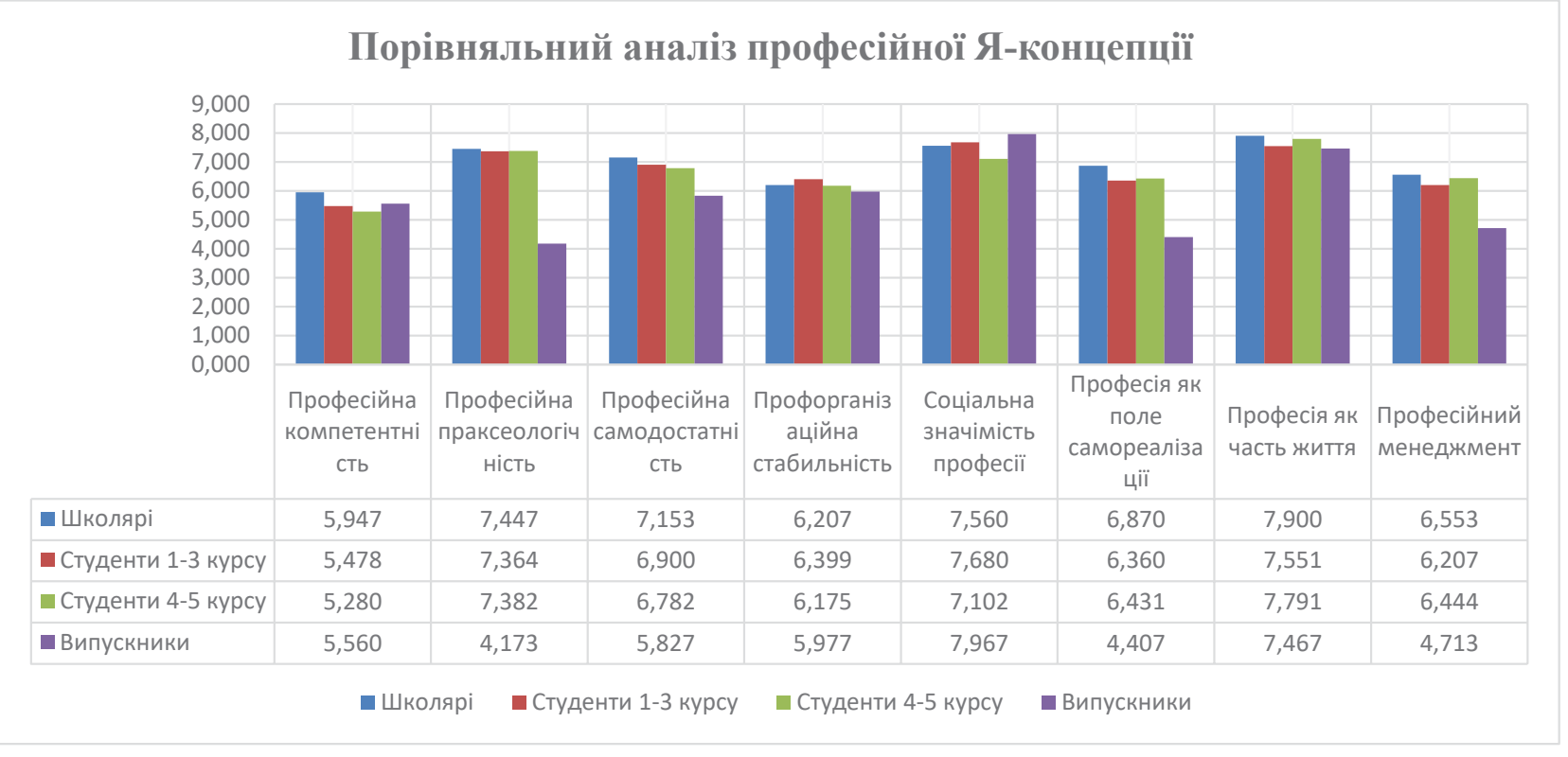

Рис. 3. Порівняльний аналіз професійної я-концепції

Цікавим $є$ той факт, що в студентів 1-3 курсів порівняно з усією вибіркою найвищі показники пов'язані 3 «профорганізаційною стабільністю». Знайомлячись із професією у виші, молоді дівчата та юнаки переймаються питанням, чи зможуть вони знайти своє місце на ринку праці. І цей пошук «себе в професійному плані» $€$ найбільш яскраво вираженим саме в групі студентів 1-3 курсів.

У групі студентів 4-5 курсів спостерігаються найбільш низькі показники порівняно з іншими групами випробовуваних у «професійній компетентності» й «соціальній значущості професії». При цьому найвищі показники в студентів 4-5 курсів, як і загальної вибірки в інтеграції стилів життя - компоненті «професія як частина життя», а також у «професійній праксеологічності» (шкала «менеджмент» за Шейном). У випускників ця шкала знаходиться, навпаки, на найнижчому показнику $-4,17$. На думку Е. Шейна, для особистості $з$ кар'єрною орієнтацією на менеджмент важливо займати посаду, на якій вона матиме управлінські повноваження щодо різних сторін діяльності підприємства: розробок, виробництва продукції, маркетингу, продажів і фінансів. Отже, ми бачимо, що для студентів 4-5 курсів однією з провідних спрямованості «Я-концепції» $€$ бажання займати керівну посаду як бажання самореалізації. При цьому 
ми можемо спостерігати, що у випускників ця потреба знижується.

У групі випускників узяли участь респонденти, які закінчили виш більше ніж 5 років тому, у них була можливість отримати професійний досвід. У дослідженні суб'єкти були віком до 37 років. Для групи випускників характерні більш низькі результати, ніж у школярів. Однак хочеться звернути увагу на те, що з підвищення віку респондентів показники в шкалі «соціальна значимість професії» зростають (при цьому незначно знижуючись у студентів 4-5 курсів), із чого ми можемо зробити висновок, що з віком і з формуванням професійної «Я-концепції» формується ставлення до професії не просто як до способу заробляння грошей, а і як бажання принести користь суспільству через професійну діяльність.

При цьому у випускників на останній план виходять такі орієнтації, як «професійна праксеологічність» і «професійний менеджмент». Тобто пріоритетом для професіоналів у діяльності вже є не бажання керувати проектами й не конкуренція, а бажання принести суспільству користь через свою професійну діяльність. При цьому це абсолютно не відкидає того факту, що особистість може займати керівну посаду, але їі справжня мотивація й мета при цьому змінюються. Відбувається трансформація професійної «Я-концепції» від особистісних потреб самореалізації через професійну діяльність до ціннісних орієнтацій використовувати професію як можливість удосконалити світ і зробити його кращим.

Висновки 3 проведеного дослідження. На підставі дослідження ми дійшли висновку, що для сучасної молоді пріоритетними ціннісними орієнтаціями є здатність інтегрувати різні сфери життя (професійну та особисту), а також соціальна важливість професії. При цьому професійна експертність не $€$ більш чимось значущим у зв'язку з динамічними змінами, яких зазнає професійне середовище через швидкий розвиток технологій і появу нових галузей діяльності.
Гендерний показник не чинить значущого впливу на професійну Я-концепцію. Однак ми виявили, що для жінок професійна самореалізація має меншу значимість порівняно з чоловіками.

Для школярів і студентів 4-5 курсів на першому місці в становленні професійної Я-концепції є орієнтація на інтеграцію різних сторін способу життя. Для студентів 1-3 курсів і випускників на першому місці виявляється «соціальна значимість професії». Відбувається трансформація професійної «Я-концепції» від особистісних потреб самореалізації через професійну діяльність до ціннісних орієнтацій використовувати професію як можливість удосконалити світ і зробити його кращим.

\section{ЛITEРATУРА:}

1. Солодилова О.П. Шпаргалка з вікової психології : навчальний посібник. Москва : ТК Велби, 2006. 56 c.

2. Марков В.Н. Потенціал особистості. Світ психології. 2000. № 1. С. 31-40.

3. Чикер В.А. Психологічна діагностика організації та персоналу. Санкт-Петербург : Речь, 2004. C. 85-96.

4. Нікіфоров Г.С. Психологія менеджменту. Санкт-Петербург : Пітер, 2004.

5. Toffler. Alvin Future Shock. Random House, 1970.

6. Давидов В.В., Маркова А.К., Шумілін Е.А. Психологічні проблеми фрормування у школярів потреби і мотивів навчальної діяльності. Мотиви навчальної та суспільно корисної діяльності школярів і студентів. Москва, 1980. С. 3-23.

7. Суворова Є.В., Андрєєва О.В., Ємець Т.В. Професійно-особистісний потенціал і параметри оцінки його розвитку. Перспективи науки і освіти. 2019. № 3 (39). C. 88-100.

8. Кузьміна С.В. Розвиток особистісного потенціалу студента з позицій компетентнісного підходу. Вісник Нижегородського університету ім. Н.І. Лобачевського. 2013. № 3 (1). С. 26-32.

9. Особистісний потенціал: структура і діагностика / ред. Д.А. Леонтьєва. Москва : Сенс, 2011. 680 с.

10. Марков В.Н. Потенціал особистості. Світ психології. 2000. № 1. С. 31-40. 